\title{
Providing Free Legal Services in Notarial Field Based on Notary Law Article 37 Paragraph (1) and (2) in Brebes Regency
}

\author{
Khairul Iman Susanto ${ }^{1}$ and Jawade Hafidz ${ }^{2}$
}

Abstract. The idea of a legal state demands the state administration and the government must be based on law and provide assurance of the basic rights of the people as stipulated in the law. Notary as a general official is appointed by the state, he/she does not receive honorarium from the State, but receives honorarium for legal services provided in accordance with his authority in accordance with Article 36 paragraph (2) of the UUJN. The purpose of this study was to analyze the meaning of article 37 paragraph (1) and (2) UUJN to notaries who provide legal services for free, to find and to analyze constraints in the application of article 37 paragraph (1) and (2) UUJN in providing services the law in the notary field to a poor person by a notary in Brebes Regency. The method used was empirical juridical and took location in Brebes Regency. The samples in this study were notary in Brebes Regency.

Keywords: legal services; free; notary.

\section{Introduction}

Article 1 paragraph (3) the 1945 Constitution of the Republic of Indonesia, hereinafter referred as the 1945 Constitution, states that the Indonesia is a legal state. The idea of a legal state demands that the administration of the state and the government must be based on law and provide assurance as the basic rights of the people as stipulated in the law ${ }^{3}$. The consequence as legal state is that every attitude, policy and behavior of state instruments and citizens must be based on and in accordance with the law. ${ }^{4}$ This is needed to avoid arbitrariness committed by both the State and its people. With the existence of law as a basis of action, it will create an order in the life of the state and society. Anyone who can be subjected to legal consequences is referred to as legal subjects. The definition of legal subjects is the holder of rights and obligations according to law or the supporters/owners of rights and obligations. Referring to Dutch law, which has been adopted by Indonesia long time ago, these legal subjects are individuals (persons) and legal entities (companies, organizations, institutions). ${ }^{5}$

An important difference between the two types of deeds is that in the proof, the authentic deed has a perfect proof. With the perfection of the notary deed as evidence, the deed must be seen as it is. There is no need to be assessed or interpreted other than what is written in the deed. The underhanded deed has the power of proof as long as the parties acknowledge it or there is no denial from either party. If the parties acknowledge it, the underhand deed has perfect verification power as an authentic

\footnotetext{
${ }^{1}$ Master of Notary's Student Sultan Agung Islamic University (UNISSULA) Semarang email khairulimans86@gmail.com

${ }^{2}$ Lecturer of Faculty of Law UNISSULA

${ }^{3}$ Ridwan HR 2002 Hukum Administrasi Negara UII Press Yogyakarta page. 68.

${ }^{4}$ Ni'matul Huda 2020 Hukum Tata Negara Indonesia Rajawali Pers Jakarta page. 80.

5 Zainal Asikin 2012 Pengantar Ilmu Hukum Rajawali Pers Jakarta page. 33.
} 
deed. However, if one party does not acknowledge it, the burden of proof is submitted to the party who denies the deed and the assessment of the denial of the evidence is submitted to the judge. ${ }^{6}$

Notary according to the Law of the Republic of Indonesia No. 2 year 2014 concerning Amendment to Law No. 30 year 2004 concerning Notary Position hereinafter referred to as UUJN is a general official authorized to make authentic deed and have other authority as referred to in this law or based on law other laws. The Notary is a part of the state that has general power and has the authority to run part of the state's power to make authentic written evidence in the field of civil law.

Notaries play a role in accommodating civil law actions carried out by the community. Notary position is not in the executive, legislative and judicial institutions, so that it can be trusted as an expert who does not take sides in making authentic deeds. Deed made by an authorized general official, it contains or describes authentically an action taken by someone, or a condition that is seen or witnessed by a general official making the deed. Authentic deeds produced by a notary can be accounted for and protect the client in carrying out legal actions. The strength of the authentic deed produced is a perfect proof for the parties, so that if a party submits an objection it can be proven at the court.

Persons with notary positions are very dignified, given the important role of notaries for the community. The behavior and conduct of a notary public in carrying out his profession must be in accordance with the code of ethics determined by the Indonesian Notary Association (I.N.A). Notary has a professional ethic, professional ethics is a moral ethic specifically created for the good of the profession in question. ${ }^{7}$ The goodness referred to is the standard of notary service to the public.

Notary as a general official is appointed by the state, $h /$ she does not receive honorarium from the state but receives honorarium for legal services provided in accordance with his authority. The amount of honorarium received by the Notary in the UUJN is not regulated in an absolute manner, but is adjusted to the conditions of each region. It is possible to have agreement to determine the honorarium between the Notary and the client, so that there is no similarity in the honorarium of the fellow Notary.

Legal services in the notary sector are needed by all classes of society. The use of notary services by the public can be done by providing honoraria to the notary. It would be rather different for the low class people who not able to provide honoraria to the notary. Differences in economic ability have an impact on the use of notary services. Basically, a notary may not refuse any client who comes to conduct legal acts in the notary field in accordance with article 37 paragraph (1) UUJN "Notary is obliged to provide legal services in the notary field free of charge to people who cannot afford it". The article shows that poor people can be given notary services free of charge.

A rule of law and the judiciary cannot be formed without regard to justice, in the establishment of a legal system and the judiciary must be guided by certain general principles. These principles concern on the interests of a nation and the State which is about justice. Since the purpose of the State and law are to achieve happiness and the

\footnotetext{
${ }^{6}$ Habib Adjie 2013 Sanksi Perdata dan Administrasi Terhadap Notaris Sebagai Pejabat Publik Refika Aditama Bandung page. 48-48

7 Sidharta 2006Moralitas Profesi Hukum Suatu Tawaran Kerangka Berpikir Bandung Refika Aditama page. 9.
} 
greatest prosperity for every person. The state is precisely thinking legally related to the idea how justice and order can be realized. ${ }^{8}$

The law is closely related to justice, even the law must be combined with justice so that it really means as law, because indeed the purpose of law is to achieve a sense of justice in society. Every law is implemented, there is a demand for justice, so the law without justice will be in vain so that the law no longer stands before the public. The objective law applies to everyone, while justice is subjective. ${ }^{9}$

In Indonesia, justice is described in Pancasila as the basis of the state, namely social justice for all Indonesian people. The values embodied in the principles of social justice for all Indonesian people are based and imbued by the precepts of God, just and civilized humanity, Indonesian unity, as well as a society led by wisdom in deliberation/representation. Therefore, in the fifth principle contained the values of justice that must be realized in a common life (social life). The justice is based on and inspired by the nature of humanitarian justice, namely justice in human relations with themselves, human beings with other human beings, human beings with society, nation and state, and human relations with their God. ${ }^{10}$

The meaning contained in article 37 (1) of the UUJN needs to be clarified, despite the attachment of "general explanation" and stated clearly. Standard qualifications for people who include in poor people needs to be more explained. Hence, the action can be implemented accordingly. Legal norms should contain normative facts that should be carried out, so they can be carried out without causing multiple perceptions in Article 37 paragraph (1) of the UUJN.

Notary positions are held or their presence is desired by the rule of law. Their presence is intended to assist and serve the public who need authentic written evidence, events or legal actions. With that basis, those who are appointed as Notaries must have the spirit to serve the community. Moreover, the people who have felt served by a notary in accordance with their duties can provide honoraria to the notary. Therefore Notary does not mean anything if people do not need them. ${ }^{11}$

Notary is bound and complies with the rules governing the position of Notary namely UUJN. These laws and regulations become guidelines for Notaries in carrying out their duties and obligations. It also contains sanctions. Notary who violates article 37 paragraph (1) UUJN, will get sanctions. In article 37 paragraph (2) UUJN mentions "Notary who violates the provisions referred to in paragraph (1) can be subject to sanctions in the form of:

- Oral warning;

- Written warning;

- Temporary dismissal;

- Dismissal with respect; or

- Dismissal with disrespect.

Sanctions are a form of government hope in order the Notary carries out article 37 paragraph (1) of the UUJN in accordance with the applicable provisions. The meaning

\footnotetext{
${ }^{8}$ Agus Santoso 2014 Hukum Moral dan Keadilan Kencana Jakarta page. 91.

9 Ibid,.page. 95.

${ }^{10}$ Kaelan 2007 Pendidikan Kewarganegaraan Untuk Perguruan Tinggi Yogyakarta Paradigma page.36.

11 Habib Adjie 2009 Sekilas Dunia Notaris dan PPAT Indonesia CV Mandar Maju Bandung page. 22.
} 
of article 37 paragraph (1) UUJN is as a determinant of the qualification of sanctions to be given to a notary public. The contradiction between das sollen and das sein is due to differences in views and principles of legal interests. The law requires the fulfillment of the rights of disadvantaged people, for the notary the condition is detrimental because the notary honorarium is obtained from the client.

Giving meaning to each person is different depending on each other's understanding. The meaning of an object is marked by a mutual agreement to refer to the word. Legal knowledge that provides benefits and certainty considers that the meaning in law must be interpreted equally. Based on the description above, the author is interested in revealing this in the form of research with the title: " Providing Free Legal Services In Notarial Field Based On Notary Law Article 37 Paragraph (1) And (2) In Brebes Regency "

Based on the description of the background presented above, the writer took the formulation of the problem, namely how the implementation, problems in applying the Notary Position Law Article 37 Paragraphs (1) and (2), and legal consequences in its implementation. In general, the purpose of this study is to analyze the application of the Notary Position Law Article 37 Paragraphs (1) and (2) carried out by Notaries.

\section{Research Methods}

This research is an empirical juridical, because it examined the Meaning of Free Legal Services done by Notaries to people (Analysis of Article 37 Paragraph (1) and (2) Law of Notary Position No. 2 year 2014). Research conducted by observing and analyzing the phenomena that occurred in Brebes Regency with the presence of a notary office that has been opened. The notary should be able to provide legal services in the notary field easily and quickly. This can improve the performance of notaries in accordance with the Act of Notary Position No. 2 year 2014 and the validity of a deed. This research tried to describe, examine and explain precisely and analyze the applicable laws and regulations associated with legal theory. This research was also expected to be able to provide a detailed, systematic, and comprehensive overview of all matters relating to the notary's obligation to provide legal services in the notary area for free to poor people. This analytical research only reached the level of description, which was analyzing and presenting facts systematically so that they can be easier to understand and infer.

\section{Results And Discussion}

\subsection{General Review of Notaries and Authority of Notaries}

In Article 1 number 1 of Law Number 2 year 2014 concerning Amendments to Law Number 30 year 2004 Notary Position (UUJN), notaries are defined as general officials who are authorized to make authentic deeds and other authorities as referred to in the UUJN. The definition given by the UUJN refers to the duties and authorities carried out by a notary. This means that the notary has the duty as a general official and has the authority to make authentic deeds and other authorities regulated by the UUJN. ${ }^{12}$

\footnotetext{
12 Abdul Ghofur Anshori 2009 Lembaga Kenotariatan Indonesia Perspektif Hukum dan Etika UII Press Yogyakarta page. 14
} 
Legal service needs in the notary sector can be given to the community and do not recognize social status, either from the capable community or the poor who need legal services must get the same service from a notary.

According to Franz Magnis Suseno there are 5 (five) parameters that can be used as a measurement of service quality when linked to the notary profession, namely: ${ }^{13}$

- Reliability is the ability of a notary in creating everything as promised;

- Assurance is the ability of a notary in creating confidence in the client;

- Tangible is the appearance of self, office, equipment and everything that is material that can increase client trust;

- Empathy is the ability of a notary to understand and feel the problems faced by clients;

- Responsiveness is the ability of the notary to provide solutions as quickly as possible to the client;

A notary in carrying out his position is required to be able to adjust his skills and performances with the development of the times which resulted in the development of increasingly complicated legal needs. According to the meaning in the dictionary, that position means work (duty) in a government or organization. ${ }^{14}$

The meaning of position like this in a general sense for each field of work (assignment) that is intentionally made for the purposes of both the good and the government and organization that can be changed as needed. Position here means Ambt. ${ }^{15}$

A notary in providing legal services to underprivileged people in accordance with the authority stipulated in the UUJN is not obliged to receive honorariums or wages. However, in the practice of notaries in Brebes Regency, especially clients who come to request legal services in the notary area are only found a few and not all notaries serve free services.

Notary in carrying out his duties is obliged to provide services to the community as well as possible, both to the rich and poor people. Notaries are also obliged to provide legal counsel to their clients to achieve high legal awareness, so that the community is aware of and fulfills their rights and obligations as citizens and community members. As Tobing explained, cited by Widyadharma as follows: ${ }^{16}$

"Efforts to improve the professionalism of notaries are not only known about the duties and position of the notary, but also what is desired by the people to be served."

Tobing's opinion above clarifies the role of notaries as general officials who are given the trust to carry out some tasks of the state that must be able to meet the needs of the community. It is really a very heavy duty and responsibility when it is interpreted correctly. When the appointment decree as a notary is dropped, and the notary is appointed in a formal juridical manner, at that time an appointment must also be made to carry out professional duties as best as possible in accordance with the Law of God Almighty and the positive law of the country where the notary is domiciled. The sanctions are not only in the form of positive legal sanctions, but also moral sanctions

\footnotetext{
${ }^{13}$ Franz Magnis Suseno 1989 Etika Sosial Jakarta: PT. Gramedia Pustaka Utama page. 69.

${ }^{14}$ Departemen Pendidikan dan Kebudayaan 1994 Kamus Besar Bahasa Indonesia Jakarta: Balai Pustaka page. 392.

${ }^{15}$ N. E. Algra H.R.W.Gokkel dkk. 1983 Kamus Istilah Hukum Fockema Andreae Belanda-

Indonesia Jakarta: Binacipta page. 159.

${ }^{16}$ Ignatius Ridwan Widyadharma 2009 Kenotariatan Indonesia Yogyakarta: UIIPress page. 106
} 
given by society and spiritual sanctions by God Almighty. When a Notary violates the nobility and dignity of the notary profession, it immediately means he violates these three things.

The interview between the researcher and notary Nur laelani $\mathrm{SH}$, during the notary practice in Brebes Regency, she said that there is no notary who has provided the provision of legal services an underprivileged client for free. The notary usually reduces the honorarium or wages for the service she made (in making a deed) in which the notary honorarium has been determined by the UUJN. These low class clients cannot be categorized as poor people, because they still have assets.

Based on the results of interviews with Nur laelani SH, she is a notary, she said that the reduction in price or notary honorarium is given if the client is unable to pay a notary honorarium in accordance with the type of deed he made. The notary will ask how capable the client is to pay the full honorarium. ${ }^{17}$

The glory and nobility of the notary profession now tends to fade away, this is due to the increasing list of names of notaries that are related to cases in the Court both civil and criminal cases. In addition to the quality of the notary who is less capable, it can also be due to the trend of the notary profession as a money printing machine. As Sugiono said, cited in Renvoi Magazine as follows: 18 "The trend is that notaries now only get money, so they don't pay attention anymore their professional job. I say this based on the frequent complaints of many clients, as well as many cases in the Court that dragged the notary as the defendant, and I was often asked to be an expert witness in the deed-making technique ".

In line with what Sugiono, Dwi Suryahartati also said that: 19 "A notary works not only oriented to profit and loss, but also burdened with social responsibility. Namely, it is obligatory to provide legal services in the notary field in a manner to those who cannot afford it. That is what is affirmed and regulated in Law Number 2 of 2014 (UUJN) ".

The explanation regarding the requirements to get free services from a notary is not regulated in detail in the UUJN.

The same thing was also expressed by Nur Halimah SH., a notary respondent. In the interview she said that a notary actually can judge the client coming to them. Is the client coming from high or low class? Does the client afford to pay the notary or not? The Notary will not ask for conditions such as a certificate from the government agency, which declare someone as poor or rich people, to obtain legal services in the notary area because by requesting these conditions according to the notary will burden the client. ${ }^{20}$

Article 37 of the UUJN states that notaries are obliged to provide legal services in the notary field free of charge to poor people, so that the application of the article in running their profession depends on the notary who is influenced by humanitarian factors, the client's candor and notary beliefs themselves. In the researcher opinion, there are several factors can be used to judge someone as capable or incapable to pay the notary. There are:

\footnotetext{
${ }^{17}$ Interviewed with Nur Laelani S.H. Notary in Brebes Regency,on 2 July 2018.

18 Hendrika Suwarti Sugiono Renvoi Edisi Nomor 11.47.IV 2007 page. 46

19 Dwi Suryahartati Peran Perguruan Tinggi Dalam Praktik Terkini Profesi Notaris yang Luhur dan Bermartabat, http://webunja.unja.ac.id/artikel/88-peranan-perguruan-tinggi-dalam-praktikterkini-profesi notaris-yang-/uhur-dan-bermartabat Diakses pada tanggal 3 Juni 2018.

${ }^{20}$ Interviewed with Nur Halimah S.H. Notary in Brebes Regency, on 2 July 2018.
} 
Volume 5 Issue 3, September 2018

- Humanitarian factors

- Factors of openness from the client

- A notary's confidence factor to the client

\section{Conclusion}

From the description of the previous discussion, the writer described the conclusions as follows:

- Arrangement of free legal assistance in the notary field for now is still guided by Law Number 30 year 2004 concerning Notary Position as amended by Law of the Republic of Indonesia Number 2 year 2014 concerning Amendments to Law Number 30 Year 2004 concerning Notary Position (UUJN) Jo. Republic of Indonesia Law Number 16 year 2011 concerning Legal Assistance (UUBH), Government Regulation of the Republic of Indonesia Number 42 year 2013 Concerning Terms and Procedures for Free Legal Aid and Distribution of Legal Aid Funds for Free, and Notary Code of Ethics. The absence of rules regarding the procedures and conditions for granting free legal aid in the notary field only makes the notary as the party providing legal assistance becomes a dilemma because it is trapped between the minimum rules of honorarium that is set by the Indonesian Notary Association and also the law order to provide free legal assistance.

- Legal consequences for notaries who refuse to provide legal assistance services in the notary area are:

- Oral warning;

- Written warning;

- Temporary dismissal;

- Dismissal with respect; or

- Dismissal with disrespect ".

But until this journal was made, there were no complaints provided by the public regarding the refusal of the notary to provide legal assistance in the notary field for free. This is because the notary has directly provided free legal consultations to the people who ask questions related to their legal interests, and will only apply fees if the community performs legal actions using a notary service whose amount of fees has been agreed upon in advance.

\section{References}

[1] Abdul Ghofur Anshori 2009 Lembaga Kenotariatan Indonesia Perspektif Hukum dan Etika UII Press Yogyakarta.

[2] Agus Santoso 2014 Hukum Moral dan Keadilan Kencana Jakarta.

[3] Departemen Pendidikan dan Kebudayaan 1994 Kamus Besar Bahasa Indonesia Jakarta: Balai Pustaka.

[4] Dwi Suryahartati Peran Perguruan Tinggi Dalam Praktik Terkini Profesi Notaris yang Luhur dan Bermartabat,http://webunja.unja.ac.id/artikel/88-perananperguruan-tinggi-dalam-praktik-terkini-profesi notaris-yang-luhur-danbermartabat Diakses pada tanggal 3 Juni 2018.

[5] Franz Magnis Suseno 1989 Etika Sosial Jakarta: PT. Gramedia Pustaka Utama.

[6] Habib Adjie 2009 Sekilas Dunia Notaris dan PPAT Indonesia CV Mandar Maju Bandung. 
[7] Habib Adjie 2013 Sanksi Perdata dan Administrasi Terhadap Notaris Sebagai Pejabat Publik Refika Aditama Bandung

[8] Hendrika Suwarti Sugiono Renvoi Edisi Nomor 11.47.IV 2007.

[9] Ignatius Ridwan Widyadharma 2009 Kenotariatan Indonesia Yogyakarta: UIIPress.

[10] Interviewed with Nur Halimah S.H. Notary in Brebes Regency,on 2 July 2018.

[11] Interviewed with Nur Laelani S.H. Notary in Brebes Regency,on 2 July 2018.

[12] Kaelan 2007 Pendidikan Kewarganegaraan Untuk Perguruan Tinggi Yogyakarta Paradigma

[13] N. E. Algra H.R.W.Gokkel dkk. 1983 Kamus Istilah Hukum Fockema Andreae Belanda-Indonesia Jakarta: Binacipta.

[14] Ni'matul Huda 2020 Hukum Tata Negara Indonesia Rajawali Pers Jakarta.

[15] Ridwan HR 2002 Hukum Administrasi Negara UII Press Yogyakarta.

[16] Sidharta 2006Moralitas Profesi Hukum Suatu Tawaran Kerangka Berpikir Bandung Refika Aditama.

[17] Zainal Asikin 2012 Pengantar I/mu Hukum Rajawali Pers Jakarta. 